\title{
Assessment of Escherichia coli 0157:H7 Contamination in Soil and Water Sources Proximal to Abattoirs Within Cross River State, Nigeria
}

\author{
Nfongeh Joseph Fuh ${ }^{1}$, Owoseni Mojisola Christiana ${ }^{1,}$, , Adogo Lillian Yami ${ }^{2}$, Upla Peter Uteh ${ }^{1}$, \\ Ekpiken Solomon Ekpiken ${ }^{3}$ \\ ${ }^{1}$ Department of Microbiology, Faculty of Science, Federal University Lafia, Lafia, Nigeria \\ ${ }^{2}$ Department of Biological Sciences, Faculty of Science, Bingham University, Karu, Nigeria \\ ${ }^{3}$ Department of Biological Sciences, Faculty of Science, Cross River University of Technology, Calabar, Nigeria
}

Email address:

dejoeman@yahoo.com (N. J. Fuh), moji.owoseni@gmail.com (O. M. Christiana), adogolillian@gmail.com (A. L. Yami), uplapeter90@gmail.com (U. P. Uteh), ekpikenekpiken@gmail.com (E. S. Ekpiken)

${ }^{*}$ Corresponding author

\section{To cite this article:}

Nfongeh Joseph Fuh, Owoseni Mojisola Christiana, Adogo Lillian Yami, Upla Peter Uteh, Ekpiken Solomon Ekpiken. Assessment of Escherichia coli O157:H7 Contamination in Soil and Water Sources Proximal to Abattoirs Within Cross River State, Nigeria. Frontiers in Environmental Microbiology. Vol. 4, No. 3, 2018, pp. 88-93. doi: 10.11648/j.fem.20180403.12

Received: May 22, 2018; Accepted: June 7, 2018; Published: July 21, 2018

\begin{abstract}
Abattoir activities generate numerous waste and microorganisms that have polluting effects on its environment and consequently could have negative impact on the health of its surrounding residents. This study assessed Escherichia coli O157:H7 contamination on adjourning soil and water sources proximal to Abattoirs within Cross River State, South-Eastern Nigeria. A total of 288 composite soils were collected into sterile polyethene bags. A total of 144 water samples were collected in triplicates aseptically into sterile $200 \mathrm{ml}$ plastic bottles. Standard microbiological and biochemical tests were carried out to isolate and identify E. coli $\mathrm{O} 157: \mathrm{H} 7$ from the samples collected. Results showed that surface and subsurface soil samples closest to abattoir slabs had highest prevalence value $(22.92 \%)$ which decreased significantly $(\mathrm{p}<0.05)$ with increase in distance away from the slabs. Spring water sources close to abattoirs had highest prevalence $(15.28 \%)$ while least value of $3.47 \%$ was obtained from boreholes. Prevalence values differed significantly $(\mathrm{p}<0.05)$ among the different water sources. Effluents generated from the abattoir causes contamination when introduced to the adjoining soil and water bodies, making them unsuitable for domestic use. The isolation of E. coli $\mathrm{O} 157: \mathrm{H} 7$ strains further demonstrates the need for adequate waste disposal and treatment.
\end{abstract}

Keywords: Escherichia coli, Abattoirs, Effluents, Wastewater, Soil Contamination

\section{Introduction}

An abattoir or slaughterhouse is a facility where animals are slaughtered for consumption as food [1]. The abattoir sector is an essential constituent of the livestock business that typically provides meat supply for over 150 million people in Nigeria [2]. Abattoirs are sources of pollution and effluents from abattoirs are commonly known worldwide to contaminate or degrade their surrounding environments whether directly or indirectly by utilizing huge amount of water and producing enormous amounts of wastewater [3-4].
Abattoir waste consists mainly of bones, undigested ingest and occasionally aborted foetuses (solid waste) while the liquid wastes comprise of blood, urine, water, dissolved solids and gut contents [5].

Environmental pollution is in the increasing trend, thereby confronting its sustainability [6] especially in cities [7] and this is a global concern. Human activities such as animal production and meat processing negatively impact on soil and natural water composition. Abattoirs in Nigeria have been known to dispose their wastes into surface water bodies without any prior treatment of the effluent which often leads to pollution of the soil, water bodies and the environment 
directly or indirectly [8-9].

The inappropriate discharge of untreated abattoir wastewater draining into the soil can cause soil oxygen to become less available as an electron acceptor, prompting denitrifying bacteria to reduce available nitrate to gaseous nitrogen which enters the atmosphere with resultant negative effects. Similarly, the anaerobic methanogens may produce excessive methane at a higher rate than aerobic methanotrophs could cope with, thus contributing to greenhouse effect and global warming. Physicochemical properties of the soil may become altered, resulting in the loss of certain soil microbes [10]. Physicochemical and microbiological qualities of soil and water samples contaminated with faecal matter from cattle have been reported to contain high turbidity values and pathogenic bacteria including $E$. coli, respectively which poses a high risk to the environmental health [11].

Pathogens present in animal carcasses or shed in animal wastes may include rotaviruses, Hepatitis $E$ virus, Salmonella spp., E. coli O157: H7, Yersinia enterocolitica, Campylobacter spp., Cryptosporidium parvum, and Giardia lamblia [12].

Improper disposal and management of these harmful wastes from abattoirs lead to various contamination to the soil, air, and water quality resulting to serious environmental hazards which can lead to broad spectrum of health complications and diseases [13-14]. Furthermore, Ojo and Alamuoye also reported that unsustainable management of slaughterhouse wastes could lead to transmission of zoonotic diseases such as colibacillosis, salmonellosis, brucellosis and helminths in humans [15].

The bacteriological characteristics of abattoir wastewater and its possible effect on receiving water bodies which is likely to cause pollution with intensified environmental and public health hazards has not been documented in Cross River, Nigeria. Therefore, the aim of this study was to assess E. coli $\mathrm{O} 157: \mathrm{H} 7$ contamination from discharged abattoir effluents on adjoining soil and water sources proximal to Abattoirs within Cross River State, South-Eastern Nigeria.

\section{Materials and Methods}

\subsection{Study Area}

This research was carried out in selected highly populated communities in Cross River State. The state is located in the Niger Delta Region, Southern Nigeria and it occupies an area of $299,10 \mathrm{~km}^{2}$ and an estimated population of 3,920,208 as at 2006 Nigeria population Census [16]. It is bounded to the North by Benue State, to the West by Enugu and Abia States, to the East by the Republic of Cameroon and to the South by Akwa Ibom State and the Atlantic Ocean.

\subsection{Sampling Design}

The study area was mapped out according to political demarcations i.e. Northern, Central and Southern Senatorial Districts. Each senatorial district was further mapped out into two sampling areas each comprising of two local Government Areas found in the state. Each sampling area was designated SA.

\subsection{Sample Collection}

Surface and subsurface soil samples were collected twice over nine months sampling period (from June 2009 to February 2010) from areas where the carcasses were displayed and at various points proximal to the slaughter slabs within the abattoirs environment. Four cardinal directions (North, South, East and West) with reference to each slaughter slab were mapped out and samples collected at points with distances of 0 (samples beside slab site), 10, 30 and $50 \mathrm{~m}$ from the carcass site. Samples from points with the same distance to the slab (irrespective of the direction of sampling) were combined to form a composite sample.

A total of 288 composite soil samples (72 from each of the four sampling points) were collected into sterile polyethene bags of about $100 \mathrm{~g}$ capacity and transported in ice cold box to the Microbiology laboratory, University of Calabar, for analysis within $24 \mathrm{hrs}$.

Water samples were collected from all available water sources reported to be used for various purposes during each slaughtering process. Sampling of water sources was carried out twice during each sampling period and in all abattoirs selected for this study.

A total of 144 water samples were collected in triplicates using aseptic techniques into sterile $200 \mathrm{ml}$ plastic bottles and transported to the laboratory in ice cold box for analysis within 6-12hrs. A total of 36-60 samples per sampling area were collected during the entire study period. Water sources sampled included boreholes, spring, wells and streams. The samples used as control were collected from an area devoid of butchering activities.

\subsection{Preparation of Water and Soil Samples}

For each sample, $30 \mathrm{ml}$ of the water source sample was transferred into a sterile $100 \mathrm{ml}$ conical flask and combined with $30 \mathrm{ml}$ of double strength $(2 \mathrm{x}$ concentration) modified buffered peptone water (mBPW, $\mathrm{pH} 7.2 \pm 0.2)$ to obtain a 1:1 dilution. The mixture was vortexed and incubated overnight at $37^{\circ} \mathrm{C}$ for $18-24 \mathrm{~h} \mathrm{[17].}$

Each soil sample was gently dried in hot air oven at $35^{\circ} \mathrm{C}$ for $1 \mathrm{~h}$ to evaporate the moisture content. The dried sample was crushed and $10 \mathrm{~g}$ mixed with $20 \mathrm{ml}$ of sterile normal saline $(0.85 \% \mathrm{w} / \mathrm{v} \mathrm{NaCl})$ and homogenized by vigorous shaking for $5 \mathrm{~min}$. The homogenized mixture was subsequently enriched by pipetting $10 \mathrm{ml}$ of mixture into 90 $\mathrm{ml}$ of buffered peptone water and incubated at $37^{\circ} \mathrm{C}$ for $24 \mathrm{~h}$.

\subsection{Sample Processing}

The diagnostic automation Enzyme-linked immunosorbent assay (ELISA) technique was used for the qualitative detection of E. coli $\mathrm{O} 157$ antigens in all enriched samples [18].

Two drops of each sample was introduced into separate 
wells until all the required number of wells (excluding the control wells) was used depending on the number of enriched samples to be assayed. Two drops of the positive and negative control solutions were also dropped into their respective wells. The contents were incubated at $37^{\circ} \mathrm{C}$ for $30 \mathrm{~min}$ and 2 drops of the enzyme conjugate added to each well. After a period of 30 min incubation, the contents were washed thrice using deionized water and 2 drops of chromogen added to each with gentle shaking. The results were compared to those of the positive and negative control wells.

A significant colour change to yellow indicated the presence of the $E$. coli $\mathrm{O} 157: \mathrm{H} 7$ antigen bound by the anti- $E$. coli $\mathrm{O} 157: \mathrm{H} 7$ antibodies impregnated in the wells. An optical density (OD) reading greater than 0.15 also confirmed a positive result.

All enriched samples with positive ELISA results were analysed using the standard E. coli O157:H7 culture technique as recommended by [19].

All enriched ELISA positive meat and faecal samples were serially diluted to $10^{-3}$ using physiological saline $(0.85 \% \mathrm{w} / \mathrm{v}$ $\mathrm{NaCl}$ ). Approximately $0.1 \mathrm{ml}$ of $10^{-2}$ and $10^{-3}$ dilutions were spread plated on sorbitol MacConkey agar supplemented with cefixime $(0.5 \mathrm{mg} / \mathrm{l})$ and potassium tellurite $(2.5 \mathrm{mg} / \mathrm{l})$ (SMAC-CT). Approximately $0.1 \mathrm{ml}$ of enriched soil samples were plated directly on SMAC-CT undiluted. Volumes of 30$50 \mathrm{ml}$ (depending on the turbidity) of enriched, ELISA positive water samples were filtered through a $0.45 \mu \mathrm{m}$ millipore filter paper before plating on SMAC-CT. All cultured samples were incubated overnight at $42^{\circ} \mathrm{C}$ for $24 \mathrm{~h}$. Sorbitol-negative colonies that appeared colourless to grey on SMAC-CT were considered positive for E. coli O157:H7. Three randomly selected suspected colonies were isolated on each plate and separately subcultured on nutrient agar slants and stored at $4{ }^{\circ} \mathrm{C}$ in a refrigerator.

Standard biochemical tests typical for $E$ coli such as indole, methyl red, Voges Proskauer, citrate and lysine decarboxylase were also performed on the isolates.

\subsection{Methylumbilliferyl- $\beta-D$-Glucoronide (MUG) Fluorescence Confirmatory Test}

All positive colonies isolated on nutrient agar slants were further inoculated into test tubes containing $E$. coli with MUG (E. coli-MUG) medium and incubated at $42^{\circ} \mathrm{C}$ for 18 $24 \mathrm{~h}$. The broth cultures were then observed under ultraviolet (UV) light of long wavelength $(650 \mathrm{~nm})$ to detect the inability of E. coli $0157: \mathrm{H} 7$ to cleave MUG (about $92 \%$ of $E$. coli other than E. coli 0157:H7 produce the enzyme glucoronidase which cleaves MUG to produce a blue fluorescent product). Positive isolates were considered as those that fermented lactose (yellow broth), produced gas (collected at the tip of the immersed Durham tubes) and did not produce any fluorescence.

\subsection{Confirmation of Escherichia coli O157:H7 by H7 Antigen Typing}

This analysis was performed using standard E. coli
O157:H7 antisera (Difco Laboratories, Detroit, Mich.) produced from rabbits and preserved with glycerol using 1:2 dilution.

Slide agglutination technique was used to test resuscitated colonies directly from sorbitol MacConkey agar (SMAC) as recommended by [20]. A wire loop was used to remove a loopful of the colony and suspended in a drop of normal saline. An equal amount of E. coli O157:H7 antiserum was added and mixed by rocking back and forth for $1 \mathrm{~min}$.

Colonies that agglutinated rapidly with the $E$. coli O157:H7 antisera were considered as confirmed positive $E$. coli $\mathrm{O} 157: \mathrm{H} 7$ colonies.

\subsection{Statistical Analysis}

The data were analysed with SPSS version 11.0 software (SPSS Inc, Chicago, IL). Percentages were compared using a Pearson chi square $\left(x^{2}\right)$ test for dependent samples or Fisher's extract " $t$ "- test where appropriate. Means were compared using the student " $\mathrm{t}$ "-test for dependant samples.

The prevalence of E. coli O157:H7 strains from various sources in soil and water samples were analysed by statistical comparison of the survival values $(\log \mathrm{cfu} / \mathrm{ml})$ of all pairs using one-way analysis of variance (ANOVA: Jump in version 4.0.3, SAS institute Inc, Cary, N. C., USA) to determine significant differences at a probability level of 0.05 .

\section{Results}

Soil samples proximal to abattoir slabs were analysed and the highest percentage prevalence of E. coli O157:H7 obtained at the following distances: Site $0(29.17 \%), 10 \mathrm{~m}$ $(16.67 \%), 30 \mathrm{~m}(8.33 \%)$ and $50 \mathrm{~m}(4.17 \%)$ with overall percentage prevalence of $22.92 \%, 9.72 \%, 3.47 \%$, and $1.39 \%$ respectively. The total percentage prevalence from all samples analysed was $9.38 \%$. The overall percentage prevalence from the various locations were observed to differ significantly at $\mathrm{p}<0.05$. Prevalence values of the pathogen at various distances to the slaughter slabs are presented in Table 1.

The effect of seasonal variations on the prevalence of $E$. coli $\mathrm{O} 157: \mathrm{H} 7$ in soil samples at different distances from the slaughter slabs were determined. The monthly prevalence of E. coli $\mathrm{O} 157: \mathrm{H} 7$ in soil samples from different locations to the slaughter slabs is shown in Table 2 . The highest monthly prevalence from site $(0)$ samples $(43.75 \%)$ was obtained in the month of January, $10 \mathrm{~m}$ samples $(18.75 \%)$ obtained in the month of June and August, 30m samples (6.25\%) obtained in the months of July, September, October, January and February and $50 \mathrm{~m}$ samples $(6.25 \%)$ obtained in the months of August and September. No significant difference $(p>0.05)$ was observed in the monthly prevalence among the site $(0)$ samples and $10 \mathrm{~m}$ samples. However, the monthly prevalence among the $30 \mathrm{~m}$ samples and $50 \mathrm{~m}$ samples differed significantly at $\mathrm{p}<0.05$ with highest values obtained during months of heavy rains.

The highest percentage prevalence of $E$. coli $\mathrm{O} 157: \mathrm{H} 7$ was 
obtained in spring water while the least value of $8.33 \%$ was obtained in borehole water sources. The overall percentage frequency of occurrence obtained were $3.47 \%, 8.33 \%$, $11.11 \%$ and $15.28 \%$ for borehole, streams, wells, and spring respectively. Significant difference $(p<0.05)$ was observed in the overall percentage frequency of isolation of $E$. coli
O157:H7 from various water sources while no significant difference $(p>0.05)$ was observed in the total frequency of occurrence from the various sampling areas. Values obtained from the various water sources in the sampling areas are presented in Table 3.

Table 1. Prevalence of Escherichia coli O157:H7 in soil samples collected at various distances proximal to slaughter slabs in various sampling areas.

\begin{tabular}{llllll}
\hline \multirow{2}{*}{ Sampling area } & \multicolumn{2}{l}{ Distance from slaughter slabs } & & \multicolumn{2}{c}{ Total prevalence (\%) } \\
\cline { 2 - 5 } & Site (0) (\%) & $\mathbf{1 0 m}(\mathbf{( \% )}$ & $\mathbf{3 0 m}(\mathbf{\%})$ & $\mathbf{5 0 m}(\mathbf{\%})$ & N=96 \\
\hline SA1 & $50(20.83)$ & $3(12.50)$ & $1(4.17)$ & $0(0.00)$ & $9(9.38)$ \\
SA2 & $7(29.17)$ & $3(12.50)$ & $0(0.00)$ & $1(4.17)$ & $11(11.46)$ \\
SA3 & $3(12.50)$ & $1(4.17)$ & $1(4.17)$ & $0(0.00)$ & $5(5.21)$ \\
SA4 & $8(3.33)$ & $2(8.33)$ & $2(8.33)$ & $0(0.00)$ & $12(12.50)$ \\
SA5 & $6(25.00)$ & $4(16.67)$ & $0(0.00)$ & $0(0.00)$ & $10(10.42)$ \\
SA6 & $4(16.67)$ & $1(4.17)$ & $1(4.17)$ & $1(4.17)$ & $7(7.29)$ \\
Overall prevalence & $33 / 144(22.9)$ & $14 / 144(9.72)$ & $5 / 144(3.47)$ & $2 / 144(1.39)$ & $54 / 576(9.38)$ \\
\hline
\end{tabular}

$\mathrm{N}=24$ for all the distances where soil samples were collected; $\mathrm{p}<0.05$

Table 2. Monthly prevalence of Escherichia coli O157:H7 in soil samples at various distances to slaughter slabs.

\begin{tabular}{llllll}
\hline \multirow{2}{*}{ Sampling month } & \multicolumn{2}{l}{ Distance from Abattoir } & & & Total frequency (\%) \\
\cline { 2 - 6 } & Site (0) (\%) & $\mathbf{1 0 m}(\mathbf{\%})$ & $\mathbf{3 0 m}(\mathbf{\%})$ & $\mathbf{5 0 m}(\mathbf{\%})$ & N=64 \\
\hline June 2009 & $4(25.00)$ & $3(18.75)$ & $0(0.00)$ & $0(0.00)$ & $7(10.94)$ \\
July 2009 & $3(18.75)$ & $2(12.50)$ & $1(6.25)$ & $0(0.00)$ & $6(9.38)$ \\
August 2009 & $2(12.50)$ & $3(18.75)$ & $1(6.25)$ & $1(6.25)$ & $6(9.38)$ \\
September 2009 & $2(12.50)$ & $1(6.25)$ & $1(6.25)$ & $1(6.25)$ & $5(7.81)$ \\
October 2009 & $1(6.25)$ & $0(0.00)$ & $1(6.25)$ & $0(0.00)$ & $2(3.13)$ \\
November 2009 & $4(25.00)$ & $1(6.25)$ & $0(0.00)$ & $0(0.00)$ & $5(7.81)$ \\
December 2009 & $6(37.50)$ & $2(12.50)$ & $0(0.00)$ & $0(0.00)$ & $8(12.50)$ \\
January 2010 & $7(43.75)$ & $1(6.25)$ & $1(6.25)$ & $0(0.00)$ & $9(14.06)$ \\
February 2010 & $4(25.00)$ & $1(6.25)$ & $1(6.25)$ & $0(0.00)$ & $6(9.38)$ \\
Overall prevalence & $33 / 144(22.92)$ & $14 / 144(9.72)$ & $5 / 144(3.47)$ & $2 / 144(1.39)$ & \\
\hline
\end{tabular}

$\mathrm{N}=16$ for total number of soil samples collected at various distances per month; $\mathrm{p}<0.05$

Table 3. Occurrence of Escherichia coli O157:H7 in water sources proximal to some abattoirs located in various sampling areas.

\begin{tabular}{lllllllll}
\hline Sampling & Borehole & \multicolumn{3}{c}{ Wells } & & Spring & \multicolumn{2}{c}{ Ttream } \\
\cline { 2 - 8 } Area & TS & PS (\%) & TS & PS (\%) & TS & PS (\%) & TS & PS (\%) \\
prevalence (\%)
\end{tabular}

- Not available, TS = Total No of samples; PS= No of positive samples; $p<0.05$

\section{Discussion}

In this study, E. coli O157:H7 contamination of adjourning soils proximal to abattoirs were analysed. High prevalence values were obtained at distances of $0 \mathrm{~m}(22.92 \%)$ and $10 \mathrm{~m}$ $(9.72 \%)$ from the slaughter slabs. Values were observed to decrease significantly $(p<0.05)$ with increasing distances away from the slabs. This observation certainly revealed the role of slaughter effluents from the slabs in the contamination of adjourning soils with greater effects experienced at distances closer to slabs. The whole body of pre-eviscerated cattle and the gastrointestinal contents of post-eviscerated ones were frequently washed on slaughter slabs. The isolation of pathogenic microorganisms including E. coli from abattoir effluents has been documented in the South East, Nigeria [21] The findings of this study is supported by Akinyeye et al. who reported that E. coli had the highest frequency of occurrence in abattoir effluents contaminated soil in Benin, Edo State, Nigeria [22]. Neboh et al. also demonstrated that the total bacterial population obtained from the contaminated soil was greater than that in the soil without wastewater contamination [23]. Ibekwe et al. reported that E. coli $\mathrm{O} 157: \mathrm{H} 7$ can survive in soil for more than 90 days which provides a very significant pathway for recontamination of the environment. The possibility of prolonged survival of E. coli $\mathrm{O} 157: \mathrm{H} 7$ in soil linked to the intensive agricultural production system pose potential risk of food crop contamination [24].

The role of runoff water from rainfall in the transportation 
of organic constituents of improperly disposed wastes is demonstrated through the observation that prevalence values of $E$. coli $\mathrm{O} 157: \mathrm{H} 7$ at far distances $(30-50 \mathrm{~m})$ to the slabs increased during the rainy periods. The effect of rainfall has also been documented [25]. In order to minimize risks of infection to producers and consumers within the study area, frequent detection of E. coli $\mathrm{O} 157: \mathrm{H7}$ in abattoir soil is required.

Water-borne E. coli O157:H7 transmissions have been attributed to the ingestion of contaminated drinking water, food processed using such contaminated water sources or recreational waters. The present study confirms the presence of $E$. coli $\mathrm{O} 157: \mathrm{H} 7$ in water sources proximal to abattoirs in Cross River State. The results showed that E. coli O157:H7 had the highest prevalence of $15.28 \%$ from spring water sources and the least value of $3.47 \%$ was obtained for borehole water with significant difference $(p<0.05)$ observed in the values obtained from the various water sources. This could suggest that abattoir activities can influence the bacterial community and serve as a source of environmental pollution to water sources proximal to abattoirs. This is in accordance to the findings of Olayinka et al. who demonstrated that abattoir effluents have environmental pollution tendency and abattoir effluents on surface water alter the microbial characteristic of the receiving water [26]. The findings of Seiyaboh and Izah also revealed that abattoir effluents had impact on bacteriological quality of tidal creek of Ikoli, Bayelsa State [27]. Receiving water bodies downstream are used for bathing, washing, watering of animals, watering of crops, and other domestic purpose and contamination by abattoir wastewater. This could result in outbreaks of E. coli O157:H7 infection through cross contamination by infected crops. One of the critical concerns with food safety is the transfer of pathogens from contaminated soil to edible portions of plants and is a is a cause for concern over threats to public and environmental health. Domestic cattle have been considered as reservoirs of Shiga toxigenic E. coli strains for human infections and abattoir effluents serve as a channel for transmission of STEC into the environment. Prevalence of STEC harbouring stx 1 and stx 2 in farm cattle have been documented in South Korea [28]. The slaughtering of cattle in the abattoir coupled with the unchecked discharge of abattoir effluent containing wastes and carcasses of these animals portends potential environmental hazards to the receiving bodies and human health [29].

\section{Conclusion}

The study reveals the presence of E. coli O157:H7 in soil and water sources proximal to abattoirs in Cross River State. The contamination of surface water and soil as obtained in this study further confirms the dangers associated with discharging untreated wastewater to the soil and surface water, thus the need for adequate treatment to ensure decontamination. Relevant health authorities should enforce compliance with requirements and regulations governing abattoir operations. The treatment of water obtained from surrounding rivers in residential areas before they are used for domestic purposes to prevent occurrence of zoonotic diseases is highly recommended.

\section{References}

[1] O. P. Canencia, M. D. Dalugdug, A. M. Emano, R. Mendoza, and A. M. P. Walag, "Slaughter waste effluents and river and catchment watershed contamination in Caygayan de Oro City, Philippines”. Env. Sci. vol. 9, pp. 142-148, 2016.

[2] W. D. Nafarnda, I. E., Ajayi, J. C. Shawulu, M. S. Kawe, G. K. Omeiza, N. A. Sani, O. Z. Tenuche, D. D. Dantong, and S. Z. Tags, "Bacteriological quality of abattoir effluents discharged into water bodies in Abuja, Nigeria," ISRN Vet. Sci., 2012, DOI: 10.5402/2012/515689.

[3] A. K. B. Amorim, I. R. de Nardiand, and N. V. Del, "Water conservation and effluent minimization: Case study of a poultry slaughterhouse" Resour. Conserv. Recycl., vol. 51, pp. 93-100, 2007.

[4] C. F. Bustillo-Lecompte, and M. Mehrvar, "Slaughterhouse wastewater characteristics, treatment, and management in the meat processing industry: A review on trends and advances. J. Env. Manag. vol. 161, pp. 287-302, 2015.

[5] J. Fearon,, S. B. Mensah, and V. Boateng, "Abattoir operations, waste generation and management in the Tamale metropolis: Case study of the Tamale slaughterhouse" J. Pub. Heal. Epi. Vol. 6, pp. 14-19, 2014.

[6] S. C. Izah, S. E. Bassey, and E. I. Ohimain, "Assessment of Some Selected Heavy Metals in Saccharomyces cerevisiae Biomass Produced from Cassava Mill Effluents," EC Microbi. Vol. 12, pp. 213-223, 2017.

[7] A. O. Akinro, O. B. Ikumawoyi, O. Yahaya, and M. M. Ologunagba, "Environmental Impacts of Polyethylene Generation and Disposal in Akure City, Nigeria" Glo. J. Sci. Fron. Res. Agri. Bio., vol. 12, pp. 1 -7. 2012.

[8] O. A. Adeyemi-Ale," Impact of abattoir effluent on the physico-chemical parameters of Gbagi stream (Odo-eran), Ibadan, Nigeria,” Ilo. Jour Sci. vol. 1, pp. 100-109, 2004.

[9] A. O. Adesemoye, B. O. Opere, and S. C. O. Makinde, "Microbial Content of abattoir waste water and its contaminated soil in Lagos, Nigeria," African Journal of Biotechnology, vol. 5, pp. 1963-1968, 2006.

[10] D. N. Ogbonna, and T. J. K. Ideriah, Effect of Abattoir wastewater on chemical characteristics of soil and sediment in Southern Nigeria. J. Sci. Res. Rep., vol. 3, pp. 1612-1632, 2014.

[11] I. T. Aighewi, E. Zimughan, and I. H. Igbinosa, "Concentrated animal wastes as urban land pollutants: a case study of Liarages in some southern Nigeria's urban agglomerations," J. Pollut. Eff. Cont., vol 5, pp. 1 -6, 2017.

[12] M. D. Sobsey, L. A Khatib., V. R. Hill, E. Alocilja, and S. Pillai, "Pathogens in Animal Wastes and the Impacts of Waste Management Practices on their Survival, Transport, and Fate. White paper for The National Centre for Manure and Agricultural Waste Management, 2002, http://www.mwpshq.org/., 2002. 
[13] S. M. Jiban, M. K. Biswas, A. Sagar, D. Suneel, and A. B. Akolkar, (2016). Slaughterhouse in Uttar Pradesh with Hygienic Environment - A Case Study," Int. J. Res. Appl. Chem, vol. 2, pp. 10-20, 2016.

[14] I. B. M. Kosamu, J. Mawenda, and H. W. Mapoma, "Water quality changes due to abattoir effluent: A case on Mchesa Stream in Blantyre, Malawi," Afr. J. Env. Sci. Tech., vol. 5, pp. 589-594, 2011.

[15] J. O. Ojo, and O. F. Alamuoye, "Bacteriological and physicochemical characteristics of abattoir effluents from Ado - Ekiti Municipal Abattoir Ekiti State, Nigeria,” Sch. Acad. J. Bio. Vol. 3, pp. 838-841, 2015.

[16] National Bureau of Statistics. (2012). Annual Abstract of Statistics, pp 23, 2012.

[17] M. Soltan-Dallal, A. Tabarraie, K. MoezArdalan, "Comparison of four methods for isolation of Yersinia enterolitica from raw and pasteurized milk from Northern Iran,” Int. J. F. Microbiol. vol. 94, pp. 87-91, 2004.

[18] Milley, D. G, and Sekia, L. H., (1993). An Enzyme-linked Immunosorbent Assay-based isolation procedure for verotoxigenic $E$. coli. Applied and Environmental Microbiology. 59 (12):4223-4229.

[19] D. Warburton, D. and D. Christensen. (2006). Isolation of $E$. coli O157: H7 or NM in foods. MFLP-80. Health Canada. The compendium of analytical methods. Polyscience Publications, Laval, Quebec, Canada.

[20] N. Pradel, V. Lirelli, C. Champs, J. B. Palcoux, A. Reynaud, F. Cheutz, F. J. Sirot, B. Joly, and C. Forestier," Prevalence and characterization of Shiga-toxin producing Escherichia coli isolated from cattle, food and children during a one-year prospective study in France," J. Cli. Microbiol. 38:1023-1031. 2000 .

[21] I. R. Iroha, O. B. Eromonsele, I. B., Moses, F. N., Afiukwa, A. E. Nwakaeze, and P. C. Ejikeugwu, "In vitro antibiogram of multidrug resistant bacteria isolated from Ogbete abattoir effluent in Enugu State, Nigeria,” Int. Res. J. Pub. Env. Heal. vol 3. Pp. 1-6, 2016.
[22] A. J. Akinyeye, W. T. Aborisade, and A. O. Akinmolayan, "Bacteriological Evaluation of Abattior effluent contaminated soil in Ikpoba, Benin, Nigeria," Res. Rev. J. Bas. Sci. vol. 1 Article ID 300020. 2013.

[23] H. A. Neboh, O. A. Ilusanya, C. C. Ezekoye and F. A. Orji, "Assessment of Ijebu-Igbo Abattoir effluent and its impact on the ecology of the receiving soil and river," IOSR Journal of Environmental Science, Toxicology and Food Technology, vol. 7 pp. 61-67, 2013

[24] A. M. Ibekwe, C. M. Grieve, and C. H. Yang, "Survival of E. coli $\mathrm{O} 157: \mathrm{H} 7$ in soil and on lettuce after soil fumigation," Can. J. Microbio. vol. 53 (5):623- 635. 2007.

[25] J. O. Nduka, and A. O. Aigberua, "Heavy Metals and Physicochemical Characteristics of soils from the Banks of Effluent Wastewater Retention Pits in the Niger Delta, Nigeria," Biotechnol Res. Vol. 4, pp. 48-53, 2018.

[26] O. O. Olayinka, O. H. Adedeji, and I. B. Oladeru," Water Quality and bacteriological assessment of slaughter house effluent on Urban River in Nigeria," J. Appl. Sci. Env. Sanit. vol. 8, pp. 277-286, 2013.

[27] E. I. Seiyaboh, and S. C. Izah, "Bacteriological Assessment of a tidal creek receiving slaughterhouse wastes in Bayelsa State, Nigeria," Journal of Advances in Biology and Biotechnology, 14 (1): 1-7, 2017

[28] H. Dong., S. Lee, W. Kim, J. An, J. Kim, D. Kim, and S. Cho, "Prevalence, virulence potential, and pulse field gel electrophoresis profiling of Shiga toxin-producing Escherichia coli strains from cattle, Gut Pathog. Vol. 9, pp. 1-16, 2017.

[29] A. A. Diallo, D. Bibbal, F. T. Lo, M. Mbengue, M. M. Sarr, M. Diouf, Y. Sambe, M. Kerouredan, R. Alambedji, Y. Thiongane, E. Oswald, and H. Brugere," Prevalence of pathogenic and antibiotics resistant Escherichia coli from effluents of a slaughter house and a municipal wastewater treatment plant in Dakar, Afr. Jour. Microbiol. Res. vol. 11, pp. 1035-1042, 2017. 